\title{
AGROTOURISM AS THE ECONOMICS TRANSFORMATION OF THE TOURISM VILLAGE IN BALI (CASE STUDY: BLIMBINGSARI VILLAGE, JEMBRANA, BALI)
}

\author{
I Wayan Ruspendi Junaedi, I Gusti Bagus Rai Utama. \\ Universitas Dhyana Pura, Universitas Dhyana Pura \\ rusfil_2001@yahoo.com, igustibagusraiutama@gmail.com
}

\begin{abstract}
In this research is focused on tourist behavior and the local communities on the demand of agro tourism development. The study is aimed at formulating the best model to develop agro tourism in Bali. The model tourist attraction is expected by the rating is community activities, plantation area, and village's uniqueness. On the amenities, the tourist expect amenities which include, among others: local accommodations, tracking area, places to gain knowledge and experience, places to rest and relax, escape area, places to meet people and interaction, places to escape the daily routine, learning experiences, and new places. On the accessibility, the tourists rate that the distance of the village of Blimbingsari as the barriers factor, and difficult to reach by public transport. In addition to a considerable distance, the path that must be passed to the Village Blimbingsari also includes the busy lanes and frequent traffic jams. The results of the research that has been done indicates that Blimbingsari tourism village been managed well which is evident from their local community involvement as tourism committee, guide services or travel agents link, local guide services that handling by tourism committee, and government support by Regent licensee.
\end{abstract}

Keywords: tourist behavior, local communities, tourist attraction, amenities, accessibility, tourism committee

\section{Introduction}

The Indonesian economy has undergone a massive structural transformation from an economy where the agriculture sector plays a dominant role in the country. Presently, approximately $45 \%$ of the total Indonesian workers are engaged on agriculture which accounted for 17\% of GDP in 2001. Some 31 million ha (76.6 million acres) are under cultivation, with $35 \%$ to $40 \%$ of the cultivated land devoted to the production of export crops. Some $60 \%$ of the country's cultivated land is located in Java (Indonesian Agricultural Department, 2005).

The agriculture sector includes food crops, horticulture, plantation, forestry, fishery, and animal husbandry. Since of various factors such as 
housing development, industries development, etc., the contribution of agriculture sector to Gross Domestic Product (GDP) becomes much less important replaced by secondary and tertiary sectors such as manufacturing industry as a new leading sector, for instance, West Java was leaded by manufacture industries, Bali by tourism sector, and Jakarta by retailing industries. As the population increases rapidly, the government seeks to achieve food selfsufficiency through expansion of arable acreage and improve the farming techniques especially the use of fertilizers and seeds, and extension of irrigation facilities, as well as expanding training for farmers. Production of rice and the staple food have increased gradually therefore rice production almost comes close to meet domestic requirements.

On the other hand, the tourism sector in Indonesia has expanded as a prospective contributor to earning of a number of local governments. Nowadays, the tourism sector is not only potential in Bali but also probable in all parts of Indonesia. The International Ecotourism Society states that Indonesia has been identified as a prospective country to develop tourism especially ecotourism. In addition, Indonesia has lots of wildlife flora and fauna as well as cultural diversities, black and white sand beaches, natural landscape, marines, mountains, etc.

Tourism has played an important role and essential source of earning. It can be evidently seen that almost all of economic activities in Bali were depended on and leaded by tourism sector. According to Pitana (2005), tourism sector is an incredible contributor to Product Domestic Regional Bruto (PDRB) for Bali. The tourism sector contributed $12.95 \%$ by $1970,17.98 \%$ by $1990,30.50 \%$ by $1997,30.49 \%$ by $1998,31.26 \%$ by 1999 , and $33.19 \%$ by 2000 . Examining further to the great contributions generated by tourism, therefore tourism sector in Bali is considered as an awaiting sector for now and upcoming year. According to Butler (1980), quoted by Gilbert (1990), the stages of tourism development comprises four stages such as discovery, launch, stagnation, and decline stages where the stages of tourism development.

Discovery Stage started since the early 1900s brought a different type of invasion and tourism began to rise. Bali's exotic beauty and culture as well as Balinese people's hospitality began to draw foreigners to the island. Some, including German painter named Walter Spies, whose home now formed as a part of Hotel Tjampuhan Ubud, decided to settle down there. Spies and other foreign artists helped to stimulate the growth of Balinese arts which were originally produced mainly to decorate temples and palaces.

Launch Stage as continue stage of the Discovery Stage started since the second president of Indonesia, Soeharto, saw Bali as one of potential tourism destinations and reopened it to tourism in the late 1960s. One of the first big hotels built was Inna the Grand Bali Beach Sanur. The host communities respond and welcome it respectively to increase the number of tourist visits by providing facilities. Businesses remain family based and the visitor-resident relationship is still harmonious. Later in this stage, the numbers of tourists increased dramatically and the local communities involved in certain tourism industries. The tourism was launched for both domestic and international tourists. For the purpose of supporting the tourism sector, the government, investors, private sectors, and small-local enterprises working together by providing infrastructures such as 
hotels, restaurants, travel agencies, tourism objects such as beaches, retailing, roads, airport etcetera. On the other hands, the superstructures such as supporting tourism organizations for instance BTDC (Bali Tourism Development Centre), BTB (Bali Tourism Board), PHRI (Indonesian Hotels and Restaurants Association), and Tourism and Hotel Colleges are established professionally.

Nowadays, the growth of tourism Bali is indicated as stagnation stage, while tourism sector has been developed in such contemporary way nevertheless the growth of tourist visit is still stagnant even though a number of promotions are continuously and intensively conducted. Furthermore, there are lots gaps between sectors, for instance: degradation of natural resources, overland using to build hotels and tourism infrastructures, air and water pollution; gap between rural and urban area, etcetera.

Presently, modern tourism development in Bali continues to attract all kinds of tourists. Some of international industries such as international- chain hotels and resorts lie on alongside the island. Its people continue to struggle over the choice between modernization and tourism, and their rich tradition. Although it has suffered some adverse social and environmental effects as a result of rapid tourism developments, Bali's cultural heritages have withstood the test of time and remained slight changes today.

The stagnation stage has been identified since 2001 up to present, where the number of international arrivals is stagnant of approximately one million visitors per year. The developments of Bali really depend on tourism sector even though dominantly the populations of Bali are still working in agriculture sector. The stagnation stage is caused by internal and external factors. Internal factors consist of urbanization problem, un- ecological development, unequal spatial where tourism development was focused southern part of Bali for instance Sanur, Kuta, and Nusa Dua without design guidelines. Meanwhile the external factors contributed to stagnation are terrorism issues, Irak war II, SARS disaster in Asia, new tourism destinations, etcetera (Pujaastawa, et al, 2005).

Additionally, according to Butler (1980), quoted by Gilbert (1990), the stagnation stage should be seen as a signal to innovate and find out alternatives to avoid the declining stage and to refine the growth of tourism. The tourism sector in Bali shall be immediately innovated and continuously developed based on sustainable tourism development concept. According to Pitana (2005), the vision and planning development of tourism in Bali shall be based on Balinese culture, as it is the only island that dominated by Hindus worshipers in Indonesia. Furthermore, Bali has a number of man-made tourism attractions and natural attractions such as lakes, mountains, beaches, and agriculture areas which should be persistently managed.

The goal of tourism development in Bali is to realize the sustainability of cultural-based tourism which developed in accordance with Tri Hita Karana concept as well as both the global market competition and improving quality of life of local communities. Tri Hita Karana is the philosophy of Balinese-Hindu which comprises three main elements namely harmonious relationship among the human being, between human and environment, and human, and the Almighty God (WTO, 2003). One of the visions of tourism 
development in Bali is to develop rural tourism based on local indigenous. It means whereas the tourism shall be developed in accordance with sustainable development principles by equality of people, profit, and planet. Without sustainable development, tourism will fail definitely to achieve the authentic goal of its development.

One of the failure factors of tourism development identified by Subadra (2006) is that tourism is un-ecologically developed. In the similar study by McIntosh, et al. (1984) quoted by Subadra (2006) describes that the development of tourism is not always successful even though developed in an ecotourism model. Yet it sometimes fails to achieve the authentic objective of development since it also causes many negative impacts such as; solid waste generation, habitant disturbance, and forest degradation which is caused by the path erosion. Therefore, tourism may not be overdeveloped and many tourists should not visit rural destinations at the same time. Moreover it sometimes fails to give economic benefits while the local communities do not directly accept the profit generated from tourism development. In many cases, local communities are frequently left out since they normally do not have adequate knowledge, skill, and attitude to involve in tourism.

Furthermore, United Nation (UNEP, 2003) mentions that development of tourism should be based on the guidelines of sustainable tourism principles and agro tourism was identified as a tourism development model which is based on environment, nature, and biodiversity. In a similar study conducted by Sudibya (2002) explains whereas the international tourists particularly the educated tourists prefer visiting the destinations which concern much on environment sustainability and nature conservation to destinations which serve modern developments. The current situation of the tourism sector in Bali is capitalistically and unequally developed since the development dominated in Southern part of Bali Island only. There is a gap between Northern and Southern part of Bali especially development of tourism sector (Pujaastawa, 2006). The great potencies of agriculture resources in Western, Middle, Eastern, and Northern parts of Bali Island have not been well developed and collaborated with tourism sector.

\section{Problem and Objective}

In this study, the research is focused on tourist behavior and the local communities on the demand of agro tourism development. The study is aimed at formulating the best model to develop agro tourism in Bali.

\section{Literature Reviews}

According to Jafari and Ritchie (1981), tourism is an interdisciplinary and integrates a variety of subjects, disciplines and focuses and can be seen from numerous points of views and approaches. The tourism as a central study can be studied from many focuses and created into a new form tourism development model. However tourism development model can be made in varying forms such as focus on agriculture as agro tourism, ecology as ecotourism, culture as cultural tourism, religion as religious tourism, etcetera.

Furthermore, Wall and Mathieson (1989) quoted by Tjokrowinoto (2002), identifies three elements of tourism system; (1) a dynamic element which involves 
travel to selected destination; (2) a static element which involves the stay in the destination; and (3) a consequential element resulted from the two preceding elements which is concerned with effects on the economic, physical and social subsystems. Some external variables such as rising earnings, mobility increase, level of education increase, and desire to escape from pressure of day-to-day urban living generate effective demands on tourism which stimulate the rise of various forms of tourisms such as recreational tourism, cultural tourism, health tourism, conference tourism, historical tourism, eco-tourism, and etcetera.

Reynolds (2005) mentions that agro tourism is businesses conducted by farmers who are working agricultural operations for the enjoyment and education of visitors. In extensions meaning, agro tourism presents the potential generating farm revenues and increasing profitability. Additionally, visitors of agro tourism contact directly with farmers and support the increase of agriculture products indirectly.

Furthermore, according to WTO (2003), that agro tourism is part of rural tourism and relates to tourism on farms. It gives farmers options to expand their activities and receive more income. Agro tourism is a small part of rural tourism and agricultural practice worldwide, excluding in some European countries such as Austria, France, Italy and Switzerland, the number of farms that offer some form of tourism is remarkably large. In some areas and countries, agro tourism forms a large part of rural tourism as a whole.

This study refers the definition of agro tourism from WTO as special interest tourism which is developed as an alternative tourism development form in Bali.

The philosophy of agro tourism is inspired to improve the farmers' earnings and the quality of rural society lives which then expectedly represents opportunity to educate the societies on agriculture and ecosystems.

Related and similar opinions described by Lobo, et al (1999), whereas the development of agro tourisms will offer opportunities for local farmers to increase their earnings and improve their lives as well as sustain their operations. The opinions can be detailed as such: (1) it educates people or society about agriculture and contribute to local economic, (2) it decrease the flood of urbanization as people are able to get jobs and earnings from agro tourism, (3) it promotes local products, and regional in marketing effort and create value added and direct-marketing and stimulate economic activity as well as give benefit to society where agro tourism developed. Rilla (1999) describes more clearly the reasons of developing agro tourism as such; (1) it educates for the purpose of keeping the relationship among local societies, interest sectors, and visitors. (2) it improves the health and freshness of visitors, (3) relaxation, (4) adventure, (5) natural food or food organic, (6) unique experiences, (7) cheap tourism.

\section{Research Methods}

Tourism sector has been developed by interactions and interconnections among linkage sectors. In the context of tourism destination as a product, it follows product lifecycle. It interacts between demand and supply dynamically. Innovations and creativities should be done to sustain the tourism development in Bali. 
The demand and supply should be identified and known by those who intend to develop tourism as well as agro tourism. The opportunity of agro tourism can be predicted by demand and supply. The demand is needed to identify the chances of agro tourism as tourism product from the consumer side and the supply is an important thing to identify of opportunities to develop agro tourism as the new economic transformation model of Blimbingsari Village.

Veal (1997) characterizes a case study as a research that involves a study of a phenomenon being exemplified and researched which is aimed at understanding the phenomenon clearly by examining an exacting example. The case study of this research will be focused in Bali Province since it is presently used as the icon of tourism in Indonesia. According to Pujaastawa, et al (2005), Bali has villages which have been developed in rural tourism form, in this case is Blimbingsari Village, where Blimbingsari Village, Melaya District in Jembrana Regency is promoted as rural tourism especially for coconut and cacao farms.

This research use direct observation, by observing agriculture areas in Bali particularly the areas which used as case studies. Also structured interview (questioner), by having direct interactions with 100 the agro tourism visitors. The data analyzed by Structured Equation Modeling (AMOS).

\section{Finding and Analyses}

Blimbingsari is a small village of approximately 200 couple families, located in western part of Bali Province approximately $120 \mathrm{~km}$ from the Capital City of Denpasar. The village was formed and developed once the Dutch colonized Indonesia. It is predominantly populated by Christian Protestant communities. Albeit it becomes a Christian village, Blimbingsari still exists in Balinese culture and tradition practices.

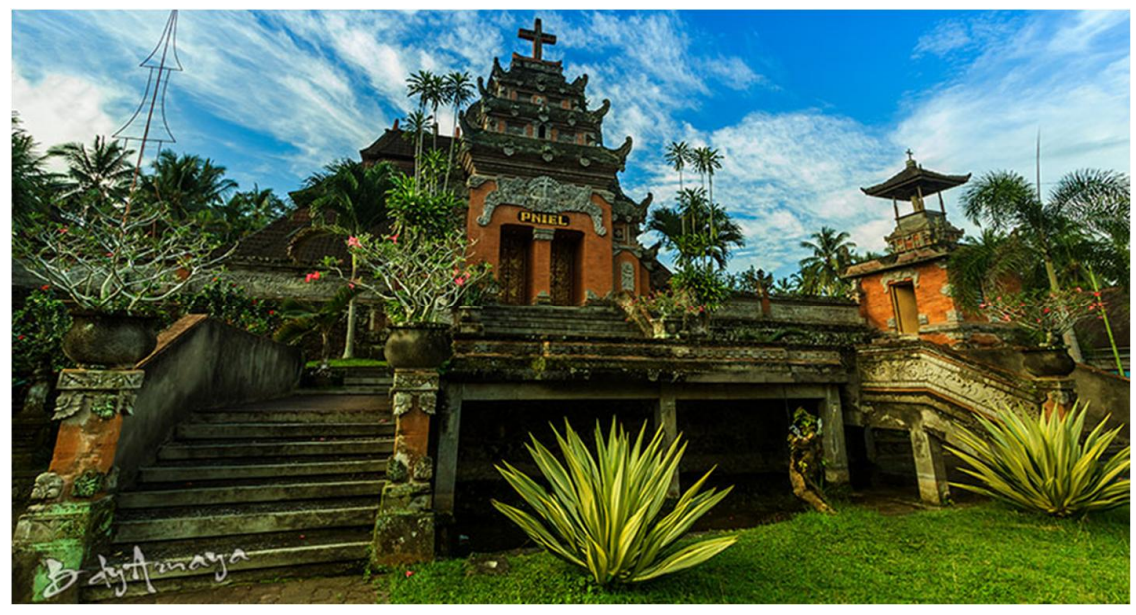

Picture 1

Balinese-style Church Building

Source: Research Observation

Predominantly, the populations work for agricultural sector. The cacao and coconut farms are the main products of Blimbingsari Village (Blimbingsari 
Village Head, 2016). The opportunity of Blimbingsari to become an agricultural attraction was motivated by "Suyaga Ayub", a pastor of Blimbingsari church. Dominantly, tourists attracted by the unique traditions of Christian communities which are implemented by Balinese-style church, and its story becomes one of the Christian villages in Bali.

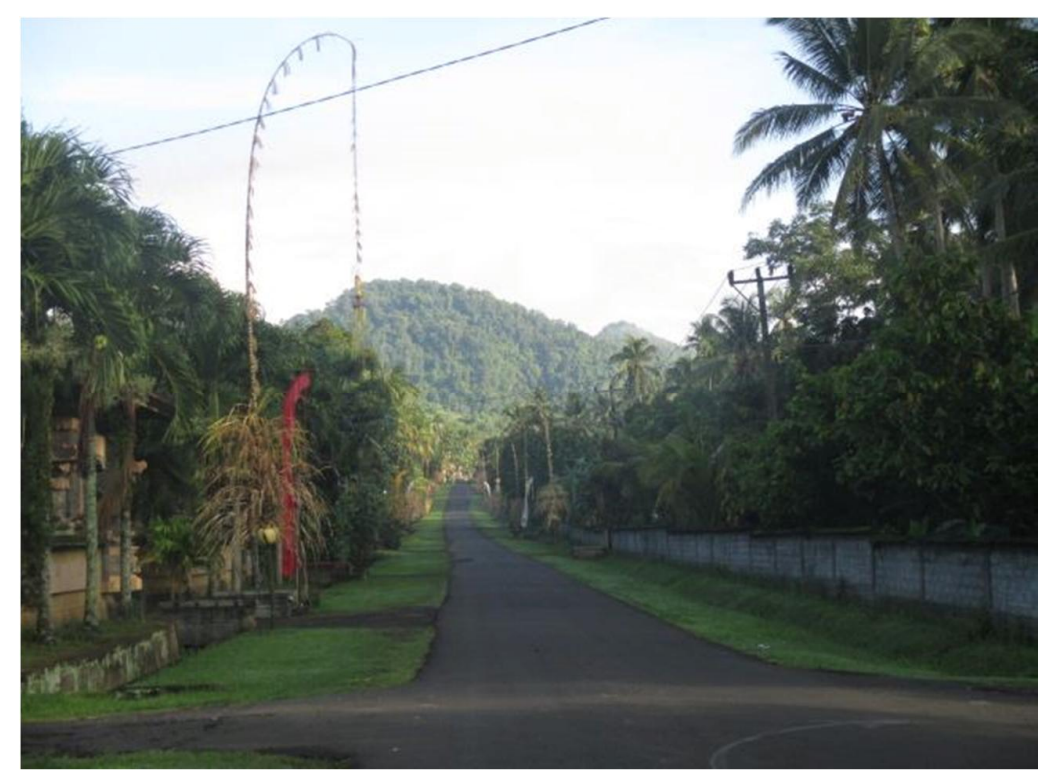

Picture 2

Cacao and Coconut Farms

Source: Research Observation

The village is also nearby Palasari Village with Catholics populations, moreover it is both close to West Bali National Park which functions as ecotourism and conservation and Palasari water irrigation (DAM) which have been developed and promoted by the local government as tourist destination in Bali.

According to farmers at Blimbingsari Village, agro tourism development is definitely enabled to increase the family income. The stakeholders predominantly agree that the agro tourism development in Bali generates certain opportunities such as; creating local employment, increasing family income, and increasing value of the village. In particular, generating related tourism business opportunities become the primary and most reasons. Agro tourism contributes lots to the improvement of economy lives of the local communities. The contributions are in the forms of agricultural products sales, several of hand-made souvenirs or handicrafts sold for the tourists, chances to establish food stalls or restaurants and certain types of accommodation such as home-stay, bungalow, villa, and hotel, as well as village development. With respect to economy improvement, the stakeholders predominantly agree that increasing agricultural products are the most contribution generated from agro tourism development. 


\subsection{Push Motivators for Visiting Blimbingsari Tourism Village}

The strong motivation to encourage tourists to visit the village of Blimbingsari is coaching physical, enrich intellect, rest and relaxation, keep away from stress, visiting family and friends, and escape from daily activities, learning and experiencing new things, and visiting new places. The full survey results can be seen in the following table:

Table 4.1

Respondents' Opinions on Push Motivational Factors

\begin{tabular}{llll}
\hline Code & Indicator & Mean & Meaning \\
\hline X1.10 & Physical training & 4.3200 & Very strong \\
X1.9 & Enriching intellect & 4.1800 & Strong \\
X1.1 & Rest and relaxation & 4.1500 & Strong \\
X1.4 & Keep away from stress & 4.1100 & Strong \\
X1.11 & Visiting family and friends & 4.0800 & Strong \\
X1.5 & Escape from everyday activities & 4.0600 & Strong \\
X1.3 & Learning and experiencing new things & 3.9300 & Strong \\
X1.2 & Visiting new places & 3.8100 & Strong \\
X1.6 & Meet people and socialize & 3.5000 & Weak \\
X1.8 & Try the challenge / experience and adventure & 3.4700 & Weak \\
X1.7 & Improve health & 3.2100 & Weak \\
\hline
\end{tabular}

Source: Pitana (2005)

\subsection{Pull Motivators for Visiting Blimbingsari Tourism Village}

The strong motivation attract tourists to visit the village of Blimbingsari is the rural community involvement, service bureau, the availability of lodging, life rural community activities, areal plantation village, village uniqueness and local tour guide services. The full survey results can be seen in the following table:

Table 4.2

Respondents' Opinions on Pull Motivational Factors

\begin{tabular}{llll}
\hline Code & Indicator & Mean & Meaning \\
\hline X2.15 & Village Community Involvement & 4.3400 & Very strong \\
X2.13 & Services Bureau & 4.1000 & Strong \\
X2.6 & Lodging & 4.0600 & Strong \\
X2.3 & Village Community Activities & 4.0500 & Strong \\
X2.2 & Plantation Village & 3.8700 & Strong \\
X2.1 & The uniqueness of the Village & 3.7900 & Strong \\
X2.14 & Local Tour Guide Services & 3.6200 & Strong \\
X2.7 & culinary & 3.5100 & Weak \\
X2.5 & Panorama of Village & 3.4600 & Weak \\
X2.10 & Distance from Airport & 3.2400 & Weak
\end{tabular}




\begin{tabular}{llll}
\hline Code & Indicator & Mean & Meaning \\
\hline X2.8 & Public facilities & 3.0700 & Weak \\
X2.11 & Distance from Capital & 3.0400 & Weak \\
X2.4 & Cultural / Indigenous / Traditional Peoples & 3.0300 & Weak \\
X2.12 & Availability of Transportation & 3.0000 & Weak \\
X2.9 & Visitor Center & 2.8600 & Weak \\
\hline
\end{tabular}

Source: Pitana (2005)

\subsection{Sustainability of the Blimbingsari Tourism Village}

Sustainability of rural tourism depends on the loyalty Blimbingsari traveler looks of willingness to recommend friends or family, and the desire to come back. Sustainability tourist village Blimbingsari also require government support and the support of local communities that are currently still included weak because only some of the villagers involved in the tourist village. Furthermore, operationalization of variables agro tourism sustainability translates into four indicators comprising:

Table 4.3

Respondents' Opinions on Sustainability Factors

\begin{tabular}{llll}
\hline Code & Indicator & Mean & Meaning \\
\hline Y1.1 & Willingness to recommend friends or family & 4.1700 & Strong \\
Y1.2 & The desire to revisit & 4.0100 & Strong \\
Y1.4 & Government support & 4.0000 & Strong \\
Y1.3 & Support local communities & 3.2300 & Weak \\
\hline
\end{tabular}

Source: Sutjipta (2001) 


\section{Agro Tourism Model for Blimbingsari Tourism Village}

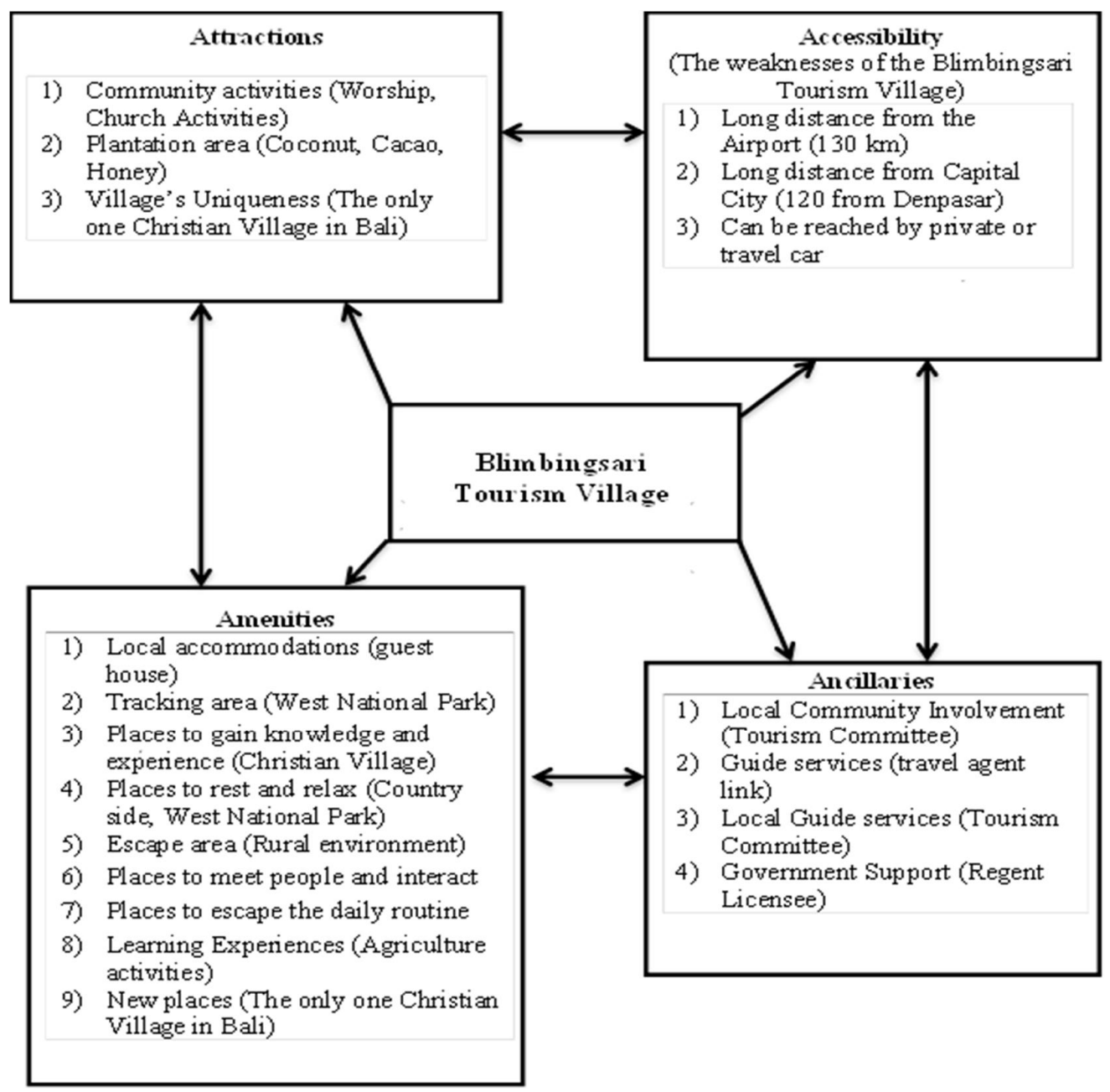

Figure 4.1

Agro Tourism Model for Blimbingsari Tourism Village

\section{Conclusion and Recommendations}

The model tourist attraction is expected by the rating is Community activities (Worship, Church Activities), Plantation area (coconut, cacao, honey), and village's uniqueness (the only one Christian village in Bali). On the amenities, the tourist expect amenities which include, among others: local accommodations (guest house), tracking area (west national park), places to gain knowledge and experience (Christian village), places to rest and relax (country side, west national park), escape area (rural environment), places to meet people and interaction, places to escape the daily routine, learning experiences (agriculture activities), and new places (the only one Christian village in Bali). On accessibility, the tourists assume that the distance of the village Blimbingsari Travel far enough, and difficult to reach by public transport. In addition to a considerable distance, the 
path that must be passed to the Village Blimbingsari also includes the busy lanes and frequent traffic jams.

The results of the research that has been done indicates that Blimbingsari tourism village been managed well which is evident from their local community involvement (tourism committee), guide services (travel agents link). local guide services (tourism committee), and government support (Regent licensee).

The solution that the distance from the capital can be overcome by making special travel packages that allow travelers can stay at the Village Blimbingsari, and combined with a package of eco-tour, especially eco-tourism to Bali Barat National Park. It would be better if, the travel packages can be packaged as a weekend's holiday package, so tourists can see and be involved directly in the activities of the church on the day of week.

\section{ACKNOWLEDGEMENT}

The authors thank the Indonesian Ministry of Research, Technology, and Higher Education (Ristekdikti) that has provided the grant necessary (2016) to conduct this research on agro tourism. The authors also thank Universitas Dhyana Pura, specifically the Chair of Research and Community Development at the university.

\section{REFERENCES}

About Agritourism Retrieve 12 November 2006 from http://www.farmstop.com/aboutagritourism.asp

Afandhi, Aminudin. (2005). Etika Pembangunan dan Pengembangan agrowisata di Indonesia (Ethics of Agrotourism Development in Indonesia). Jakarta: University of Trisakti Indonesia.

Agenda 21. (2006) The Travel Tourism Industry; towards Environmentally Sustainable Development, WTTC, WTO, The Earth Council.

Agricultural Tourism Small Farm Center and Partners Launch Agricultural $\begin{array}{lllll}\text { Tourism } & \text { Project, } & 12 & \text { November } & 2006\end{array}$ http://www.sfc.ucdavis.edu/agritourism/agritour.html

Bali Tourism Board. (2006). Official website of the Bali Tourism Board, Denpasar, Retrieve 22nd May 2007 from http://www.bali- tourismboard.com

Barbier, Edward B. (1989). "Cash Crops, Foods Crops, and Sustainability: The Case of Indonesia." World Development, vol. 17, no. 6, pp. 879-895.

Becken, S. (2004). How tourists and tourism experts perceive climate change and forest carbon sinks. Journal of Sustainable Tourism. 
Butler, Richard, and Hall, C. Michael. (2003). Tourism and Recreation in Rural Areas. New York: John Wiley \& Sons.

Cooper, Chris, at al. (2005). Tourism: Principles and Practice. London: Pearson Education Limited, Third Edition.

Cooper, Chris. (2003). Aspects of Tourism: Classic Reviews in Tourism, Sydney: Channel View Publication.

Dalem, A. A. G. R. (1999). Birds as a potential tourist attraction at Nusa Dua lagoon, Nusa Dua, Bali, Indonesia. A preliminary study. pp. 159-172. Proceedings of the International Seminar of Sustainable Tourism: The Balinese Perspective in Denpasar, Bali.

Eadington, W.R. and Smith, V.L. (1995) Introduction: The emergence of alternative forms of tourism. In V.L. Smith and W.R. Eadington (eds) Tourism Alternatives: Potentials and Problems in the Development of Tourism (pp. 1-12). Philadelphia: University of Pennsylvania Press.

Gilbert, A.J. (1990). Natural Resource Accounts in drylands management. In Dixon, J.A., D.E. James and P.B. Sherman. Dryland Management: economic case studies.

History of Bali, Retrive 12 February 2007 from http://uk.holidaysguide.yahoo.com

http://geographyfieldwork.com official website for Barcelona Field Studies Centre offers geography, biology, ecology and environmental field studies programmes throughout the year.

Indonesian Agricultural Department. (2002). Warta Penelitian dan Pengembangan Pertanian Vol.24 No.1, 2002, Retrieve 12 November 2006 from http://www.pustaka- deptan.go.id/publ/warta/w2419.htm

Indonesian Agricultural Department. (2005). “Agrowisata Meningkatkan Pendapatan Petani” 12 November 2006 from http://database.deptan.go.id

Jafari, J and Ritchie, J. (1981). Towards a framework for tourism education. Annals of Tourism Research.

Jamieson, W. and Noble, A. (2000). A Manual for Community Tourism Destination Management. Canadian Universities Consortium Urban Environmental Management Project Training and Technology Transfer Program, Ca Lindberg, K. 1996. The

Economic Impacts of Ecotourism. Retrive 12 November 2006 from http://ecotour.csu.edu.au/ecotour/mar1.htm 
Lane. (1994). Tourism Management: Profiling segments of tourists in rural areas, needs and wants. Department of Quantitative Methods for the Economy, University of Murcia, Campus de Espinardo, 30100 Murcia, Spain.

Lobo, R.E., Goldman G.E. (1999). Agricultural Tourism: Agritourism Benefits Agriculture in San Diego County, California Agriculture, and University of California.

McIntosh and Goeldner. (1990). Tourism. Principles, Practices, and Philosophies (sixth ed.), Grid Publishing, Columbus.

Mulyani, A., Wahyunto, and F. Agus. (2003). Land suitability and land use changes in Indonesia. Presented at AMAF+3 Symposium on Research and Development of Sustainable Agriculture. 25-26 Feb. 2003, Phnom Penh, Cambodia. (Unpublished).

Nugroho, K., et al. (1997). Peta areal potensial untuk pengembangan pertanian lahan rawa lebak, rawa pasang surut, dan pantai. Proyek penelitian sumber daya lahan. Pusat Penelitian Tanah dan Agroklimat. Badan Litbang Pertanian. Departemen Pertanian. Bogor.

OTA. (1992). Southeastern Rural Mental Health Research Center, University of Virginia, Madison House, 170 Rugby Road, 22903 Charlottesville, Virginia

Page, J. Stephen and Getz, Don. (1997). The business of Rural Tourism: international perspective. London: International Thomson Business Press.

Pitana, I Gede. (2005). Sosiologi Pariwisata, Kajian sosiologis terhadap struktur, sistem, dan dampak-dampak pariwisata. Yogyakarta: Andi Offset.

Postma, Albert. (2002) An Approach for integrated development of quality tourism. In Flanagan, S., Ruddy, J., Andrews, N. (2002) Innovation tourism planning. Dublin: Dublin Institute of Technology: Sage.

Primack, R. B. J., Supriatna, M., Indrawan, and Kramadibrata, P. (1998). Biologi Konservasi. 345pp. Yayasan Obor Indonesia: Jakarta.

Pujaastawa, IBG., Wirawan, IGP., Andika, IM. (2005). Pariwisata Terpadu: Alternatif Model Pengembangan Pariwisata Bali Tengah. Denpasar: Udayana University. ("Alternative Tourism Development for Middle part of Bali).

Rai Utama, I Gusti Bagus. (2015). Agrowisata sebagai Pariwisata Alternatif Indonesia. Deepublish: Yogyakarta.

Reynolds. (2005). Consumer demand for. agricultural and on-farm nature tourism. Davis, CA: University of California. 
Rilla, E. (1999). Bring the City \& County Together. California Coast and Ocean. Vol. 15, No. 2. 10p.

Schurink, Harrie, J., A. (2000). Agricultural tourism in Indonesia: Development of agricultural tourism in Central Java and Bali and the role of the government in this development.Leeuwarden:Dissertation Master of Arts International Leisure and Tourism Studies.

Spillane, James.(1994). Ekonomi Pariwisata, Sejarah dan prospeknya.Yogyakarta: Kanisius.

Statistic Agency of Indonesia/Badan Pusat Statistik. (2006). Tourism and Cultural Department, Retrieve 12 December 2006 from http://www.budpar.go.id

Subadra, I Nengah. (2006). Is Ecotourism Ecologically Developed?. Retrieve 7 June 2007 from http://subadra.wordpress.com

Sudibya, Bagus. (2002). "Pengembangan Ecotourism di Bali: Kasus Bagus Discovery Group". Makalah disampaikan pada Ceramah Ecotourism di Kampus STIM-PPLP Dhyana Pura, Dalung, Kuta pada tanggal 14 Agustus 2002.

Sutjipta, I Nyoman. (2001). Agrowisata.Magister Manajemen Agribisnis:Universitas Udayana.

Syamsu, Yoharman. (2001). Penerapan Etika Perencanaan Pada Kawasan Wisata: Studi Kasus Kawasan Agrowisata Salak Pondoh,

Kabupaten Sleman, Daerah Istimewa Yogyakarta. Jakarta. Research Center Tri Sakti Tourism College.

Tambunan, Tulus. (2006). Long term trends in the industrial and economic growth in Indonesia, Center for Industry and SME Studies, Faculty of Economics, University of Trisakti Indonesia.

Tjokrowinoto. (2002). Tourism Information System of Indonesia. Yogjakarta, Gajah Mada University

Trochim, (2006). Social Research, Retrieve 7 May 2007 from http://www.socialresearchmethods.net/

UNDP.(2005). The crisis in Bali's tourism sector, The objectives of the UNDP Bali Crisis Recovery programme. Retrieve 22nd July 2007 from http://www.undp.or.id/programme/conflict/bali_crisis.asp

UNEP. (2003). UNEP publications that provide information on the tourism industry, Agenda 21- The Role of Local Authorities in Sustainable 
Tourism. $\quad$ Retrieve 12th May 2007 from http://www.uneptie.org/pc/tourism/library/home.htm

Veal, A.J., (1997). Research Methods for Leisure and Tourism: a Practical Guide. London: Pitman.

Veer , Marije., and Tuunter, Erik. (2005). Rural tourism in Europe: An exploration of success and failure factors. Raamweg: Stichting Recreatie, Expert and Innovation Centre

WTO. 2003. World Tourism Organization. (2000).Tourism Trends. Madrid 